\title{
Religion and State in Contemporary Turkey: Recent Developments in Laiklik
}

\author{
James W. Warhola and Egemen B. Bezci
}

\section{Background}

Turkey was established as a secular republic in 1923, and was the first predominantly Moslem country to formally do so; significantly, the Turkish population is overwhelmingly Sunni Moslem regarding formal religious identification. The meaning of "secular republic" has varied over time, however, and has certainly varied in interpretation by the relevant actors in Turkish political life, including popular perceptions of what secularism should mean. The word itself is ambiguous and may carry a wide array of meanings; the Turkish word, laiklik $^{1}$ is as intrinsically ambiguous as its

\begin{abstract}
JAMES W. WARHOLA (B.A., Ohio Northern University; M.A., Ph.D., The Ohio State University) is professor of political science, The University of Maine. His articles have appeared in Religion, State and Society, Journal of Church and State, The Nationalities Papers, Democratization, The American Journal of Political Science, Forum on Public Policy, Nationalism and Ethnic Politics, The International Journal of Politics, Culture, and Society, and The Carl Beck Papers in Russian and East European Studies. Special interests include politics and religion in comparative perspective and ethnic politics. He was visiting research fellow at Bilkent University, Ankara, Turkey, Spring 2010. EGEMEN B. BEZCI (B.A., Bilkent University) is a student, Department of International Relations, Bilkent University, and research intern, International Center for Terrorism Studies, Arlington, Virginia. He has written an article which appeared in Tel Aviv Notes. Special interests include civil-military relations, politics and religion in the Middle East, and international security.
\end{abstract}

1. "Laiklik" is a Turkish word, derived from the French "laicite," meaning roughly secularism; the principle of laiklik was one of the "six arrows" at the foundation of the modern Republic of Turkey. The other five were republicanism (cumhuriyetçilik), statism (devletçilik), nationalism (milliyetçilik), populism (halkçıllk), and reformism, sometimes also translated as "revolutionism" (devrimçilik).

Journal of Church and State vol. 52 no. 3, pages 427-453; doi:10.1093/jcs/csq052 Advance Access publication July 20, 2010

(C) The Author 2010. Published by Oxford University Press on behalf of the J. M. Dawson Institute of Church-State Studies. All rights reserved. For permissions, please e-mail: journals.permissions@oxfordjournals.org 
French-derived origin, laicite. ${ }^{2}$ In the Turkish context, however, it was initially instituted to convey a certain disposition of civil authority to religion in which the state itself actively embraced and fostered a nonreligious worldview in the public realms (such as partisan politics, public education, media, etc.). This approach has been called "active secularism" as opposed to a politically "passive secularism," on the part of the state, as is claimed to prevail in the United States. ${ }^{3}$ This article provides evidence that the Republic of Turkey has been experiencing an array of political pressures to move away from its historical "active secularism" to a more passive type. Regardless of where these pressures lead, they have already changed the political landscape of Turkey in a significant manner. Below we describe how and why this is so.

On November 3, 2002, Turkey's fifteenth general parliamentary election was won by the Justice and Development Party, known in Turkish as the AK Party, an avowedly Islamic-oriented party that had evolved from several previously extant Islamic parties. Since that election, few would dispute that the character of religionstate relations in Turkey has changed, but precisely how it has done so is a matter of considerable dispute. This article explores the contours of that change, provides an account of them, and offers commentary on the likely directions of religion-state relations in Turkey. With a population of over seventy-four million, a military estimated to be the eighth largest in the world, and a vibrant economy of around 7 percent average annual growth since the AK Party came to power until the recession of 2009, Turkey is a pivotal country geographically, geostrategically, and in terms of religion and politics in the Islamic world. Thus the manner in which political secularism is changing in Turkey is highly significant.

The principle of political secularism in the Turkish republic has received extensive treatment in the scholarly literature; for our

2. The deepest etymological origin, however, is from the ancient Greek, "laos," or people in general, as distinguished from clerical figures. In the HellenisticGreek New Testament, it is used over 140 times, in many but not all cases connoting a religious distinction of the general folk from religious leaders; Thayer and Smith, "Greek Lexicon Entry for Laos," The New Testament Greek Lexicon, http://www.searchgodsword.org/lex/grk/view.cgi?number=2992 (accessed November 27, 2009).

3. Ahmet T. Kuru, "Reinterpretation of Secularism in Turkey: The Case of the Justice and Development Party," in The Emergence of A New Turkey, ed. M. Hakan Yavuz (Salt Lake City: The University of Utah Press, 2006), 13739. See also his much more expansive treatment of this theme in Secularism and State Policies toward Religion: US, France, and Turkey (New York: Cambridge University Press, 2009). 
purposes, a very brief overview will suffice. ${ }^{4}$ Historical sources of Turkish laiklikinclude the ideas of the Young Turks in the latter nineteenth and early twentieth centuries, Atatürk's ideas, and the heavy role of Western influences on the post-Ottoman Turkish military; ironically perhaps from a Western perspective, even various Ottoman practices have been viewed as a source of the secular character of the twentieth-century Turkish Republic. ${ }^{5}$ When the Republic was established on October 29, 1923, a particularly grave responsibility was assumed by the military to safeguard the secular character of the Turkish state, despite the fact that the principle of political secularism was not codified in the Constitution until 1928. These historical roots played a role in the historical germination of a pattern of religion-state relations in the twentieth century that shaped the character of the Turkish state. According to one interpretation, a major underlying reason for the actively secular character of the Turkish state is that, since religion in Moslem societies was arguably even more pervasive and thorough-going in defining, shaping, and guiding society than was Christianity in doing so in its respective societies, it was imperative that the secular state in Turkey have a more active role in guiding and controlling religion in society than was the case in politically "passively secular" societies, the prime exemplar of which is the United States. ${ }^{6}$

\section{Religion and State in Contemporary Turkey: The Domestic Dimension}

Turkey's statehood thus was founded at the outset on a strict distinction between public religion and state authority. However, this

4. Major works include Niyazi Berkes, The Development of Secularism in Turkey (New York: Routledge, 1998); Soner Cağaptay, Islam, Secularism, and Nationalism in Modern Turkey: Who Is a Turk? (New York: Routledge, 2006); Barry Rubin and Ali Çarkoğlu, Religion and Politics in Turkey (New York: Routledge, 2005) (previously published as a special issue of Turkish Studies). It should be noted that the secularism demanded by the Turkish constitution has never taken the form of essentially forced secularization of society as occurred in the USSR under the Communist Party's avowed aim of creating a new type of society in which religion was to have been eventually abandoned by the population as an unscientific and outmoded worldview.

5. Metin Heper, "The Ottoman Legacy and Turkish Politics," Journal of International Affairs 54, no. 1 (2000): 63-82.

6. Kuru, Reinterpretation of Secularism in Turkey: The Case of the Justice and Development Party, 145. This view is not universally shared; however, as an interpretation of the early Kemalist conception of laiklik; one view has it that Atatürk's intent and plan were for a "cognitive revolution" of secularization, from which the political transformation into a secular state would thereafter derive, taking the political form of laicite, as laiklik (the authors thank Dr. Metin Heper for pointing this out). 
did not mean then, nor does it mean today, that the Turkish state was not to involve itself in religious affairs; quite the contrary. A particular understanding of secularism prevailed in Turkey from the outset, and that historical understanding implied state control of religion: the American constitutional principle of "free exercise of religion," both as an abstract juridical ideal and as a practical guiding principle for adjudication, is not characteristic of Turkish laiklik, and this must be grasped in order to understand the contemporary disputes over the proper role of the state in religious matters. Significantly, among the various official institutions composing the Turkish state, this concept of laiklik has been consistently and staunchly supported by the military. This is doubly significant because the military has been the most popularly trusted state institution throughout the experience of the Turkish republic. The military has consistently acted as the defender of both "democracy against democracy" and secularism. ${ }^{7}$ This is no small matter given the widespread popular perception that the internal enemies of the Republic are as great and as menacing as any external threat, particularly as of the latter 1990s. ${ }^{8}$

Internally, the various Islamist movements and the Kurdish question were perceived as the main threats to both the foundational principles of the Turkish state, and its practical, immediate viability: if the "Islamists (however defined) took over, laiklik would be no more; if the Kurds succeeded in dismembering Turkey to create an independent state, the Kemalist Republic would be fatally, territorially compromised. Therefore, the military may be seen as the defender of a strict Jacobin-type secularism."9 However, the victory of the AK Party in the 2002 election and formation of the first one-party government (as opposed to a coalition government) in seventeen years changed the balance between religion and state. This trend was further augmented and fortified by the prospect of EU accession in a complex interplay of domestic and international factors, explored in more detail below. The roots of the so-called Islamic movement that eventually manifested itself in the AK Party's electoral victory of 2002 in Turkey are to be found in the 1980s; in the ensuing decades, it underwent

7. Metin Heper, "Conclusion-The Consolidation of Democracy versus Democratization in Turkey," Turkish Studies 3, no. 1 (2002): 138-46.

8. Lerna Yanik notes that the Turkish "National Security Concept" of 1997 places radical Islam and Kurdish separatism at the top of the list of threats to Turkey, reflecting a general shift in emphases of post-cold war threat perception from external to internal ones; see "Allies or Partners? An Appraisal of Turkey's Ties to Russia," East European Quarterly XLI, no. 3 (2007): 356-58.

9. See Hakan Yavuz, The Emergence of a New Turkey: Democracy and the AK Parti (Salt Lake City: University of Utah Series, 2006). 
various changes, which we explore below. ${ }^{10}$ Those changes have been described as an "identity rupturing" of Turkish politics and society, and as such cannot have failed to produce significant political ramifications.

The Turkish military nonetheless consistently played a central role in both general elite-level politics, and specifically in safeguarding laiklik as a fundamental political principle. Significantly, the question of religion, the state, and society manifested itself to a greater or lesser degree in each of the four military coups d'etat undertaken in the Republic: in 1960, the top civilian leadership was placed under arrest and Prime Minister Adnan Menderes was hanged on September 17,1961 , along with his foreign minister and finance minister. In 1971 the military again intervened, supplanting the government of Suleyman Demirel and ruled for two years; on September 12, 1980, the military struck again, resulting in a sea change in Turkish elite politics that one account describes as "Turkiye'nin Miladi" (the birthday of Turkey). ${ }^{11}$ Finally, in 1997 the military staged a "soft coup," demanding that the government resign-or else. Since the military's ultimatum accused the political leadership of violating the norms of laiklik, the government had good reason, based on precedent, that the threat of direct military intervention was credible indeed. Accordingly, the government compliantly resigned.

The 1990s witnessed a continuation of the increasing degree of religiosity among the Turkish public that had its roots in the 1980s. This trend continued into the new century, seemingly gaining momentum in the early twenty-first century. In November 2002 an avowedly Islamic party, the Justice and Development Party (Adalet ve Kalkinma Partisi, or AK Party), won a strong plurality of

10. Ali Bayramoğlu, Modernity Does Not Tolerate Superstition: The Religious and Seculars in the Democratization Process (Ankara: TESEV, 2009), 41:

The rise of the Islamic movement in Turkey occurred around the mid-1980s with the obvious influence of the Iranian Revolution. The movement reached its zenith in the 1990s and led to a severe polarization of religion and secularity. This 20-year period is of uttermost importance for the inner buoyancy of the Islamic segment and the recreation of an Islamic identity. It is both a time of integration, and a period of differentiation due to the conflicts and interactions experienced by the Islamic segment both within itself and with the secular segment. In other words, while this period created the politically and socially differentiating cornerstones of the Islamic identity after 1980, the experiences and confrontations during that time have had radical effects on the Islamic segment and have triggered a wave of change. (emphasis added)

11. Mehmet Ali Birand, Hikmet Bila, and Ridvan Akar, 12 Eylül: Türkiye’nin Miladi (Istanbul: Doğan Kitapçılık, 1999). 
votes in the general election (34 percent) which, owing to the very high electoral barrier of 10 percent, garnered the party 363 of 550 parliamentary seats, easily enough to form the government. The only other party to gain seats was the Republican People's Party (Cumhuriyet Halk Partisi) - the party of Atatürk. The questions of the role of religion in Turkish society-and of its relationship to the state-were central to this election. In the next parliamentary election of July 2007, the AK Party increased its proportion of the vote to 46.6 percent, but won 23 fewer seats, at 341, since two other parties had this time passed the 10 percent barrier (the highest in the world, incidentally, and deliberately set very high by the military in 1983). Polat notes:

Throughout the [2007] general election campaign, the AKP managed to present itself as the victim of military intervention, and as the defender of the "civilianisation" of Turkish politics. The AKP took obvious advantage of being victimised in the presidential election while also portraying itself as the champion of democracy. The presidential question dominated the campaign on two levels: Secularism (How secular was the AKP's candidate?) and the role of the Army in politics (should the Army intervene to protect secularism?). The AKP insisted several times that it does not have any problem with secularism and that secularism should be understood in tandem with the other characteristics of the regime laid down in the Constitution. ${ }^{12}$

The reason that the AK Party had to "insist several times" that it would abide by the Constitutionally mandated secularity of the state is because its motives were not trusted. ${ }^{13}$

Did the AK Party represent the sort of clerical-type threat that had served as the alleged foundation for the "soft coup" of 1997? In many respects this question has been central to Turkish politics, and has dominated it, since that event; accordingly, there is no easy or straightforward answer to it, and popular, journalistic, and scholarly opinion has varied dramatically. Özbudun viewed the transformation of the AK Party itself into a mainstream political party as having "monumental significance" not only for Turkeyand particularly Turkish democracy-but also for the region, and indeed the entire Islamic world:

the transformation of Turkish political Islam, once considered a serious threat to the stability of democracy, into a moderate conservative democratic party is a development of paramount importance in Turkish

12. Rabia Karakaya Polat, "The 2007 Parliamentary Elections in Turkey: Between Securitisation and Desecuritisation," Parliamentary Affairs 62, no. 1 (2009): 138.

13. This theme is pursued in depth in Ioannis Grigoriadis, "Islam and Democratization in Turkey: Secularism and Trust in a Divided Society," Democratization 16, no. 6 (2009): 1194-1213. 
politics. This development can be seen as a significant step toward bridging the age-old deep cleavage between secularists and Islamists, thus contributing to the consolidation of democracy in Turkey. The success or failure of the AKP experience is likely to have repercussions beyond Turkey's borders and in the entire Islamic world. This radical change from the practice of older Islamist parties seems to have been a function of the realization by a wing of the former Islamist parties (RP and FP) that challenging the secular character of the state in Turkey would be futile. ${ }^{14}$

At this point the role of the military in this question must be considered more deeply, since it has regarded itself - and has been rightly regarded by much of the population-as the bulwark of the state's secular character amid the religious turmoil of the Near and Middle East.

\section{Military: Guardians of the Secular Republic}

The Turkish military has long had complex relations with the civil authorities and with Turkish society. For decades the military acted as the guardians of "democracy against [too much] democracy" by using power via certain channels such as the Presidency, the National Security Council (MGK), and other state institutions, including even the Ministry of Religious Affairs (Diyanet Işleri Bakanliği). Nor was this pattern historically novel for the Republic-its roots also are to be found in the Ottoman period. ${ }^{15}$ Two major factors shape the ideas behind military intervention: the first concerns the perception of threat according to the Turkish military. According to the military, Islamic fundamentalism and Kurdish separatism became the most prominent domestic threats to the Turkish State, and the military held the obligation to protect the secular state by all means necessary. ${ }^{16}$ As noted above, by the latter 1990s these internal threats were perceived as the most menacing ones. Also, and somewhat paradoxically, the military thus acts as

14. Ergun Özbudun, "From Political Islam to Conservative Democracy: The Case of the Justice and Development Party in Turkey," South European Society and Politics 11, nos. 3-4 (2006): 555.

15. Even in Ottoman Turkish statehood, military intervention occured; several sultans, e.g., Alemdar Vakası (1808) and Bab-ı Ali Baskını (1913), were forced to resign by the military.

16. Turkish Armed Forces Internal Service Law No. 211 of January 1961. Article 35 states: "The duty of the Turkish Armed Forces is to protect and preserve the Turkish homeland and the Turkish Republic as defined in the constitution." Republic of Turkey Ministry of Justice, "Turkish Armed Forces Internal Service Law," Mevzuat Bilgileri, http://www.mevzuat.adalet.gov.tr/html/1044.html (accessed February 12, 2010)_Gareth Jenkins's translation in "Continuity and Change: Prospects for Civil-Military Relations in Turkey," International Affairs 83, no. 2 (2007): 343. 
the guardian of laiklik even though the nation's obligatory military service is popularly associated with religious motives. Military service is obligatory for every young healthy male in Turkey, reflecting a longstanding martial tradition, long and well recognized by allies and foes alike. ${ }^{17}$ Further, many Turks still refer to Turkey as an Asker Millet-a military nation, reflecting an integral component of the national identity. ${ }^{18}$ Significantly, this trait is curiously admixed with a religious element, e.g., Turkish soldiers are traditionally called Mehmetçiks, referring to the Prophet Muhammad, and military service is Peygamber Ocağl-the Prophet's House. Also, the essentially religious concepts of Şehadet (martyrdom) and gazi (veteran) refer to key values of Turkish society. Thus a certain degree of inherent ambiguity, or even tension, exists regarding the military's role as defender, not only of the state and the nation, but also particularly of the state's secular character. Again, given the increased salience of religion in public life, it was perhaps inevitable that such tension would manifest itself more openly in the political process, and indeed it has done so. ${ }^{19}$

On closer inspection, the military's intervention in civil politics in the name of protecting secularism stems from a variety of historical and sociopolitical dynamics that have played themselves out differentially in each case of overt intervention, and even in the ongoing, often very subtle, intervention in national governance in between the coups d'etat. The legacy of the Western-oriented Young Turks, the effective military rule during the War of Independence (1919-1922), the legacy of Atatürk's "six arrows" (of which laiklik is one), and the deep, tight cultural fusion of military and religious symbols and expressions make for a profoundly complex tapestry in which laiklik works itself out in concrete practice. Since this overall pattern of historical dynamics shaped the evolution of the military elite, civil-military relations in Turkey are unique. Therefore, traditional theories of civil-military relations are only marginally capable of providing an accurate explanation of the patterns of the early twenty-first century; e.g., Huntington's professional army theory is not particularly helpful in explaining the Turkish military's unique position. ${ }^{20}$

17. Scott Taylor, Unreconciled Differences: Turkey, Armenia, and Azerbaijan (Ottawa: Esprit de Corps Books, 2010), particularly ch. 4, "The End of the Ottomans," 90-110.

18. Ersel Aydınl, Nihat Ali Özcan, and Doğan Akyaz, "The Turkish Military’s March toward Europe," Foreign Affairs 85, no. 1 (2006): 77-90.

19. Ronald Inglehart and Pippa Norris, Sacred and Secular: Religion and Politics Worldwide (New York: Cambridge University Press, 2004).

20. Literature on civil-military relations in Turkey is extensive, predictably reflecting not only conflicting Western interpretations and models but those in Turkey as well. Even Chief of Staff General İlker Başbuğ stated that such theories can only reflect a portion of the complex, historically conditioned realities 
A more accurate understanding of contemporary civil-military relations demands an understanding not only of the historical role of the military in the Ottoman and Republic periods, but also of the mindset and apparatus of the military and the general populationand for that, the religious dimension is crucial. Again, the contemporary situation is intriguing and significant precisely because of the shifts in the content and form of that dimension.

The Turkish military's understanding of democracy is akin to Giovanni Sartori's rational democracy theory. ${ }^{21}$ Therefore, two major issues have arisen for the military in the past generation in particular: modernization (meaning in this case essentially westernization), and maintaining order. For both roles, protecting laiklik was fundamental, to the point of determining for itself the extent, timing, and circumstances of intervention in civilian governance. Historically, a significant element of that determination has been ongoing suspicion that ostensible religious motives might serve as a pretext for political ambition, to the point of fatally threatening laiklik. Thus historically, the military employed several major channels of influence on civil government: the presidency, the MGK, and various other state institutions such as state security courts, and even indirect control of the Religious Affairs Ministry. Beginning in 1999 and accelerating under the AK Party government since 2002, however, the military's influence on civil government has declined, to the point where the "Ergenekon" affair and even the "Balyoz" affair beginning January 2010 resulted in dozens of arrests of current and retired high-ranking military officers on charges of illegally plotting another coup d'etat. Matters became so strained that a summit meeting was held among Prime Minister Erdogan, President Gül, and military Chief of Staff General Başbuğ on February 25, 2010, the results of which were a temporary political truce, but whose long-term effects appear certain to portend a continuation of the shift in the character of laiklik. ${ }^{22}$

of the present period, e.g., those of Samuel Huntington, Morris Janowitz, and Eliot Cohen. İlker Başbuğ, "Chief of Staff Gen. Başbuğ's Annual Evaluation Speech at the Turkish Military Academy 14 April 2009," Turkish General Staff, http://www.tsk.tr/10_ARSIV/10_1_Basin_Yayin_Faaliyetleri/10_1_7_

Konusmalar/2009/org_ilkerBaşbuğ_harpak_konusma_14042009.html

(accessed December 3, 2009). Also see: Nil S. Şatana, "Transformation of the Turkish Military and the Path to Democracy," Armed Forces \& Society 34, no. 3 (2008): 357-88, and Nilüfer Narlı "Civil-Military Relations in Turkey," Turkish Studies 1, no. 1 (2000): 107 -27, for overviews of the pertinent scholarly literature. 21. Aylin Güney and Petek Karatekelioğlu, "Turkey's EU Candidacy and CivilMilitary Relations: Challenges and Prospects," Armed Forces \& Society 31, no. 3 (2005): 443.

22. For a summary of the Ergenekon and Balyoz affairs, as well as a summary statement of the military's declining influence, see “The Turkish Army: Coups 
The tripartite coalition government preceding the AK Party's acquisition of authority in 2002 was in the process of pursuing EU candidacy, and amended several articles in the Constitution that would result in a decline of the power of the MGK. ${ }^{23}$ These included, for instance, the appointment of two additional civil ministers to the MGK, so that such civilians would wield a majority in the council; this ran utterly counter to the intention of the military governments that initially established the MGK following the first military coup in 1960. Even more dramatic changes occurred under the AK Party government in 2002, which appointed a civil secretary to the MGK and changed the frequency of the meetings from once in a month to once in every two months. During this reform period, then-chief of staff General Hilmi Özkök also played a crucial role. A grand coalition formed between the military and civilian authorities to bring Turkey to the final step of modernization-namely full EU membership. ${ }^{24}$ In this period, two prominent instruments of military influence on civil government were transformed, namely abolition of the State Security Court, and the MGK being brought decisively under civilian authority. General Özkök faced a serious challenge by the upper echelons of the military establishment during his term, but prevailed.

Moreover, as of this writing, there are ongoing investigations and trials regarding a plot to overthrow the government by coup d'état. General Özkök's successor General Büyükanıt was generally seen as more favorable to protecting secularism. Also the presidential election held during his term was significant. The presidency in Turkey stands as a symbol of Atatürk's legacy and historically the president was elected from among retired Generals-until the presidency of Turgut Özal (December 1989-October 1993). Even the presidential palace-Çankaya-is often regarded as the symbolic but institutionalized statement of laiklik. Further, the president had been elected by the parliament until 2007 when a popular referendum-sponsored by the ruling AK Party-changed the procedure to direct popular election. This precipitated a near-crisis situation,

Away," The Economist, February 13, 2010, 56-57. It offers: "If Turkey's army is beginning to lose its addiction to political meddling, it is in part thanks to the efforts of the man at the top. General Başbuğ, who won a reputation for toughness in the early 1990s during the height of the Kurdish insurgency in southeast Turkey, is as strict a secularist as any. But he is well aware that the army's perceived aversion to Islam has contributed to its sagging popularity."

23. That government was composed of three rather ideologically incongruous political parties: Democratic Left Party (DSP), the rather right-leaning National People's Party (MHP), and the probusiness Motherland Party (ANAP), forming a coalition led by left-leaning prime minister Bülent Ecevit.

24. Ersel Aydinli et al., The Turkish Military's March toward Europe, 77-90. 
the core substance of which was, again, the meaning of laiklik: during the 2007 presidential election, the AK Party's candidate, Abdullah Gül, and his head-scarf-wearing wife, raised in bold relief the matter of what it means to have a self-avowedly Islamic-oriented political party ruling over an avowedly, constitutionally mandated secular state. In the pre-election atmosphere, the meaning of laiklik became in some respects the main issue; at the very least, it was certainly an issue for every political party. Society became polarized regarding the issue, and meetings were held in major cities with the participation of hundreds of thousands, mostly claiming to protect secular political structure. ${ }^{25}$ The Secular-Nationalist RPP (Republican People's Party-CHP) appealed to the Constitutional Court on April 27, 2007, to cancel the presidential elections in the parliament; moreover, the same day the military issued a press release by warning that the Chief of Staff was "watching the question of secularism with deep concern." This was clearly a veiled threat to intervene again. ${ }^{26}$

The above statement, which is referred to as an e-muhtıra (e-memorandum), implied two concerns. It showed that the military would, regardless of the EU accession process, intervene in the civil politics when secularism was threatened. Nevertheless, for the first time in Turkish politics an elected government, the AK Party, stood against the military's threat of intervention in civil politics. Then-spokesman of the government Cemil Çiçek replied to the e-muhtıra with an even stronger declaration:

It is unthinkable that in a state governed by rule of law, the TGS [military] as an institution under the Prime Minister, would speak against the government. The TGS is an institution under civilian governmental command, and its duties and responsibilities are defined by the constitution. According to our constitution, the Chief of Staff is responsible to Prime Minister because of the Chief of Staff's stated duties and authorities. ${ }^{27}$

25. “Tarihi Mesaj (Historical message)," Milliyet, April 15, 2007.

26. Turkish General Staff, "Press Release No:BA- 08/07 Date: 04.27.2007," Press Releases, http://www.tsk.tr/10_ARSIV/10_1_Basin_Yayin_Faaliyetleri/10_1_ Basin_Aciklamalari/2007/BA_08.html (accessed December 2, 2009):

Türk Silahlı Kuvvetleri yapılmakta olan tartışmaların ve olumsuz yöndeki yorumların kesin olarak karşısındadır, gerektiğinde tavrını ve davranışlarını açı ve net bir şekilde ortaya koyacaktır. Bundan kimsenin şüphesinin olmaması gerekir.

27. In the original Turkish: Başbakana bağlı bir kurum olan Genelkurmay Başkanlığı'nın herhangi bir konuda hükümete karşı bir ifade kullanması demokratik bir hukuk devletinde düşünülemez. Genelkurmay Başkanlığı, hükümetin emrinde, görevleri Anayasa ve ilgili yasalarla tayin edilmiş bir kurumdur. 
This unequivocally forceful and in fact unprecedented response by the government changed the environment of civil-military relations; it also shifted the meaning of laiklik to a certain degree. And after the Constitutional Court cancelled the first round of the presidential elections, the AK Party government found another solution for the presidency. The Prime Minister and leaders of the AK Party brought an initiative to change the Constitution, if necessary by a referendum, and by going for an early parliamentary election. ${ }^{28}$ The early parliamentary elections were held on July 22, 2007, resulting in the AK Party increasing its share of parliamentary seats by gaining 46.7 percent of the popular vote. Even the party leadership did not expect such an overwhelming victory. Then, on August 28, the presidential election was held, with the AK Party candidate Abdullah Gül elected. Finally, a popular referendum on September 21, 2009, was held to amend the Constitution so as to provide for popular election of the president for a five-year renewable term. The referendum also changed the parliamentary term of office from five years to four years. These events indicated that public favor of military involvement in civil politics was waning. This trend increased after General İlker Başbuğ was appointed as Chief of Staff on August 30, 2008, replacing General Büyükanit. This change of personnel led to a gradual shifting toward what might be called a Huntingtonian perspective, with clearer safeguards for civilian control. ${ }^{29}$

Even though the demilitarization of Turkish politics had advanced substantially in the early twenty-first century, numerous questions and problems remained even after the events of $2007 . .^{30}$ Various plots to overthrow the government by a coup d'état,

Anayasamıza göre, Genelkurmay Başkanı görev ve yetkilerinden dolayı Başbakan'a karşı sorumludur.

For the full text see: http://www.radikal.com.tr/haber.php?haberno=219798 (accessed Februrary 12, 2009).

28. "Hodri Meydan (I dare you!)," Yeni Şafak, February 05, 2007.

29. General Başbuğ's speech on April 14, 2009, reframed the new aspect of civil-military relations and thus to a degree laiklik itself:

Huntington'a göre, silahlı kuvvetler üzerinde sivil otoriteye en sağlıklı ve en etkin kontrolü sağlayan norm, "objektif kontrol"dur. Objektif kontrol ise, askerlik mesleğinin profesyonel yeteneğinin artırılması ve askerlerin politikadan uzaklaştırılması ile sağlanır. Bunun doğal neticesi olarak da askerlere kendisini organize etme ve görevlerini yürütme açısından önemli boyutta otonomi verilmelidir. Elbette bu otonominin boyutları yasalarla belirlenmelidir.

30. The term "demilitarization" is from Dimitris Tsarouhas and Özkan Duman, “'Civilianization' in Greece versus 'Demilitarization' in Turkey," Armed Forces and Society 32, no. 3 (2006): 405 -23. See also Nilüfer Narli, "Civil-Military 
known as Ergenekon, including various businessmen, academics, politicians, and military officers, were still under investigation and trial by judges and prosecutors as of the writing of this article. Another such set of cases revolving around the Balyoz ("Sledgehammer") affair, noted above, are ongoing; these were front-page news on a daily basis in the early months of $2010 .^{31}$ Whatever the results of these investigations, the military was no longer the unequivocal guardian of laiklik, and Turkey took one more step toward the consolidation of civilian democracy-and a trend toward a more "passive secular" type regime.

Yet these events raise the question of the political motive behind the shift from Turkey's "active secular" regime to a more "passive secular" type. Did Turkey in fact face a genuine, bona fide threat of Islam-based radicalism as the political-partisan strength of the AK Party increased during the 2000s, as charged by the defenders of Turkey's traditional version of laiklik? Noted Turkish scholar Metin Heper concludes that it emphatically did not; we find his reasoning compelling. ${ }^{32}$ He explains:

the cognitive revolution that the founders of the Turkish Republic tried to make has been quite successful, and, as a result, (1) the Turkish people,

Relations in Turkey," Turkish Studies 1, no. 1 (2000), who in 2000 correctly predicted a diminution of the role of the military (p. 121):

Given the structure of Turkish society, efforts to discredit the military will lead to political turmoil rather than increased democratization at a time of political instability. Most important for Turkey's future stability is the capacity of civilian governments to maintain harmonious relations with the military. Relations are challenged by the political tension that has risen between social classes and antagonism between the military and radical groups. More democracy, greater prospects for European Union membership, and enhanced political stability will reduce the military's political influence. Restoring Turkey to a functioning democracy will ease the civil-military partnership and produce civilian dominance.

This forecast materialized to a signficant degree by 2010, despite the presently questionable progress toward EU membership.

31. The so-called Balyoz affair involved a number of accusations against various figures in the military establishment, alleging that they concocted detailed plans to launch a coup, as they saw necessary, depending on the nature and direction of political change in Turkey-meaning an unacceptable departure from laiklik.

32. Metin Heper, "Does Secularism Face a Serious Threat in Turkey?," Comparative Studies of South Asia, Africa, and the Middle East 29, no. 3 (2009): 413-22. See also, Taha Aykol, "Dindarlik ve laiklik," Milliyet, October 20, 2009, www.milliyet.com.tr/Yazar.aspx?aType=YazarDetayPrint\&ArticleID=1164084 (accessed November 20, 2009). 
the pious as well as the nonreligious, have come to have loyalty to the secular republic; (2) on the whole the pious are secularized and voluntarily separate religion and politics; and, consequently, (3) the loyalties of the pious to the secular state do not contradict their religiosity. ${ }^{33}$

Further, it appears that the underlying social changes in Turkey are not working against these traits but rather reinforcing them. After briefly considering these, we turn to the question of the manner in which forces coming from Turkey's overall pattern of foreign relations appear to be further reinforcing them.

\section{Changes in the Character of Civil Society in Turkey: Consequences for Laiklik}

In 2009 Ali Bayramoğlu of the research group TESEV offered the following summary assessment of the changing character of religiosity in Turkey:

This research basically asserts that while the Islamic segment is becoming secular on its own, the secular segment is also democratizing. These are the dominant attitudes of the majority. Rigid Islamic and secular attitudes constitute the minority. Today the election results, other political manifestations, and all societal indicators and measures confirm these general attitudes. ${ }^{34}$

The continued modernization of Turkey, especially since the 1980s, occurred alongside, and perhaps was causally related to, a more conscious religiosity among a significant sector of the population; this much is clear. However, it is still not clear how much, and among which sectors these changes occurred. Nonetheless, Bayramoğlu et al. offer the following:

the Islamic movement, especially with the inputs of this approach and the economic and social changes of the 1980s, has not refrained from producing its own wave of modernity. The gains of the interactivity initiated between Islamic actors and the modern sphere have been passed on to the depths of the Islamic segment, especially by women, where they have affected a range of elements, from gender relations to the traditional division of roles. However, the same change paved the way for an assertive politicization; a dominant, confident, questioning and demanding movement that fed on the above mentioned globalist wave. In this context, the Islamic movement was politicised through the tension between lifestyle and habitat, and was defined by the "identity" or the "identity oriented inclination" with which it reconstructed and reformed its social attributes. $^{35}$

33. Ibid., 414.

34. Ali Bayramoğlu, "Modernity,” TESEV, April 2009, 6.

35. Ibid., 92. 
There is evidence that much of the impetus for a changed role of religion has been from the newly emerged business class. The same TESEV report also offers:

Certainly, the result of the latest general elections (July 2007 and March 2009) may be interpreted as a significant outcome of the longitudinal and profound period of transformation whose main dynamics are documented in this research. As we have professed in the conclusion, the transformation process has basically originated and been led by the middle class. On the other hand, the transformation process also works backwards and includes elements that reshape the middle class in relation with political attitudes and expectations. As a matter of fact, the majority of the secular and the Islamic segments share similar views on issues such as democracy, freedom and human rights. ${ }^{36}$ (emphasis added)

The proportion of votes won by religiously oriented political parties in the general parliamentary elections rose from single digits in the 1970s to around one-quarter in the 1990s; in the 2002 and 2007 parliamentary elections, the figures were nearly 70 percent. Moreover, since the military regime of the early 1980s, civil society organizations in Turkey have generally increased in number and in influence. ${ }^{37}$ According to Freedom House, Turkey has experienced a generally favorable pattern of political change during the past decade: it began and ended the first decade of the twenty-first century being "partly free," although its scores on "political rights" improved from 4 to 3, and "civil liberties" improving from 5 to 3 from 2002 to 2009 (7 point scale, 1 being highest). ${ }^{38}$ Since this question so directly involves the role of religious groups, and the role of religion in society and governance, it is worth investigating more closely.

Civil society is the metaphorical "space" between the individual citizen and the state; it is "civil" to the extent that various groups composing society-including religious ones-have an autonomous

36. Ibid., 13.

37. Sarah Repucci, “Country Report: Turkey,” Freedom House, available online at http://www.freedomhouse.org/uploads/ccr/country-7291-8.pdf (accessed January 1, 2010):

Civic groups have grown in strength and number since the 1980s when they were mistrusted and tightly controlled. State-societal relations have improved, and civic groups have become more engaged in public policy. (p. 6)

She goes on to note, however, that NGOs are often taken to court, and those advocating human rights (particularly regarding the Kurdish issue) are especially targeted.

38. Freedom House, "Country Report: Turkey," Freedom in the World, available online at www.freedomhouse.org/template.cfm?page $=22 \& y e a r=2009 \&$ country =7722 (accessed February 11, 2010). 
sphere of activity, more or less from state control. In a political system characterized by civil society, such groups, or individual citizens acting as such, control the state, rather than vice versa. Civil society in Western Europe generally emerged as a result of free-market economics and commerce as well as other cultural/intellectual forces. The emergence of civil society in Turkey followed similar patterns as in Western Europe, however, only considerably later in time, and with some of the cultural/intellectual forces operating adventitiously. In Turkey, the rise of civil society generally occurred as a consequence of liberalization and integration into the world market starting from the 1980s; yet the more recently emerging civil society and economic networks are organized around religious poles. These include various Sufi orders, reading circles, and faith organizations.

Traditional Islamic understanding suggests that the unity of state and religion (din wa dawla) is an integral part of the faith. ${ }^{39}$ Islamic political movements generally emphasize social solidarity and a central role for the state in the enforcement of that solidarity, rather than individual autonomy per se. Thus somewhat paradoxically perhaps, recent civil Islamic movements have been more focused on individuals and personal relations rather than group solidarity, which they appear to take more or less for granted. Moreover, they have tended to organize as grassroots movements. Turkey has experienced dramatic social and economic transformation since the 1980s, as noted above; perhaps the most prominent in this period has been the emergence of new "spaces," metaphorically, between the state and society. ${ }^{40}$ By pursuing increasingly liberal economic policies, the state's previous social monopoly was challenged on a variety of issues; examples include private TV channels, private universities, and an increasing array of trade and professional organizations. Liberalization and deepening integration of the economy into the global market beginning in the latter 1980s also had an impact on traditional social dynamics. The Turkish business elite, which was based in Istanbul and mostly supported by government incentives and tariffs, formed a de facto coalition with the military. Also, the Kemalist progressive elites joined this coalition, which then served as the locomotives and symbols of Turkish modernity. ${ }^{41}$ However, liberalism and

39. Nilüfer Göle, "Authoritarian, Secularism and Islamics Politics," in Civil Society in the Middle East, ed. Augustus Richard Norton (Leiden: E. J. Brill, 1996), 2: 17.

40. Ziya Öniş, "Turgut Özal and His Economic Legacy: Turkish Neo-Liberalism in Critical Perspective," Middle Eastern Studies 40, no. 4 (2004): 113-34; Hasan Cemal, Özal Hikayesi (Istanbul: Doğan Kitap, 2000).

41. Murat Gültekingil and Tanıl Bora, eds., Modern Türkiye'de Sìyasi Düşünce Cilt 2: Kemalizm, 6th ed. (Istanbul: İletişim Yayınları, 2009). 
integration to the global market stimulated the emergence of an Anatolian bourgeoisie and an alternative (i.e., nonsocially secularized) modernity. As a result of the rising of an Anatolian business class, traditional Istanbul-based capital looked for new markets with which to integrate, and thus increasingly oriented itself into the European Union accession process. This Istanbul-based bourgeoisie thus revised its ties with the army and the Kemalist elite. Because of the significance of this trend, it will be useful to examine the new Anatolian business class more closely.

The Anatolian business class is usefully organized into several different forms, with correspondingly different aspects of political significance regarding religion and politics. First, there is the Independent Businessmen's Association (MÜSİAD), formed in 1990 by a group of conservative-religious industrialists and businessmen who separated from the Turkish Industrialists' and Businessmens' Association (TÜSİAD). Second, there is The Union of Chambers and Commodity Exchanges of Turkey (TOBB), which played a more traditional role in the development of civil society. Established in 1950, it describes its purpose thus:

TOBB aims, parallel to the developments elsewhere in the world and in its capacity of the highest level representative of the Turkish private sector, at ensuring unity and solidarity between chambers and commodity exchanges, enhancing development of the professions in conformance with general interest, facilitating professional work of members, promoting honesty and confidence in the relations of members with one another and with the general public, and preserving professional discipline and ethics. ${ }^{42}$

The Islamic scholar Ali Bulaç described TOBB as having energized and propelled itself into a much more active role in Turkish society, with consequent changes in its manner of governance. ${ }^{43}$ More generally, the emergence of the Anatolian business class challenged the definition of secularism in Turkey. Kahraman notes, we believe essentially correctly, that "Turkish secularism removes Islam from the public space, completely limiting it to conscience and personal

42. TOBB, "Purposes of TOBB," from its official Web site, http://www.tobb.org. tr/eng/tobbhakkinda/purposes.php (accessed on February 24, 2010).

43. Ali Bulaç, "Darbeler ve TOBB," Zaman, January 15, 2010:

Hisarcıklıoğlu'nun başında bulunduğu TOBB, Anadolu'nun beşeri ve iktisadi enerjisini, gücünü ve ileriye dönük performansını temsil eder. Üyeleri, asli ana gövdeleriyle 1929'dan beri CHP'nin 6 ok'undan biri "devletçilik" ilkesinin arkasına gizlenerek devletten beslenmiyorlar... . Yaşadığımız büyük politik ve fikri değişimin iktisadi boyutunu ne TÜSİAD ne onu taklit eden MÜSİAD doğru okuyor. Anadolu iktisadi alanda da kendi mecrasını bulacaktır. 
private practice and space and never refers to it as a part of administrative process." ${ }^{44}$ After the foundation of the Republic, various interpretations of Islam, Sufi orders, and dervish lodges with the use of religious titles were banned. ${ }^{45}$ Moreover, only one Orthodox Hanafi school of Islam is tied to state control by the Ministry of Religious Affairs. State intervention in religious affairs has historically been a manifestation of the prevailing concept of laiklik as it pertained to society's perceived need for progress in modernization-particularly the military's concept of progress, as noted above. But as also noted above, that entire picture of civil-military power relations is changing, and is doing so largely on the basis of the underlying changes in society. The alternative modernity of Islamic movements in Turkey has mostly focused on individuals and civil life, rather than demanding a top-down, clerical-type organizational structure of society. As Yavuz accurately indicated: "In Turkey, the economic reforms were welcomed and embraced by society-centered Islamic movements that appropriated Islamic symbols for the marketplace to encourage the production of religious interpretations, values, and meaning through business and patterns of consumption." 46

Liberal economic policies since the latter 1980s also spawned the emergence of a new urban middle class. Both the rising Anatolian bourgeois and the rising urban middle class adopted a curious lifestyle combining traditional rural values with urban norms. The new urban population, who are rational, religious, and urbanized, depended on various networks to accommodate themselves to the new city life. This situation created a new type of civil society, newly rooted in urban market relations, but whose worldview has been directly shaped by traditional concepts of Islam. ${ }^{47}$ Viewed from this perspective, it is easy to see, in retrospect, how Islam became increasingly salient, politically, despite the context of a secular state in which these social changes were occurring. But what social forms did these changes assume? Two major Islamic movements in contemporary Turkish society are particularly important, namely the Nakşibendi Sufi Order and Fethullah Gülen Movement.

\footnotetext{
44. Hasan Bülent Kahraman, "From Culture of Politics to Politics of Culture," in Remaking Turkey, ed. Fuat Keyman (Lanham: Lexington Books, 2007$), 57$.

45. Tekke ve Zaviyelerle Türbelerin Seddine ve Türbedarlıklar ile Birtakım Unvanların Men ve İlgasına Dair Kanun, November 30, 1925; for the full text, see: http://www.mevzuat.adalet.gov.tr/html/390.html.

46. Hakan Yavuz, "Opportunity, Spaces, Identity and Islamic Meaning in Turkey," in Islamic Activism: A Social Theory Approach, ed. Quinton Wiktorowicz (Bloomington: Indiana University Press, 2004), 270.

47. Hakan Yavuz, Islamic Political Identity in Turkey (New York: Oxford University Press, 2003), 81.
} 
The Nakşibendi Sufi Order has networks and branches in a variety of countries from Central Asia to Europe. In Turkey, there are numerous branches and most operate under the Khaliddiye School, namely the İsmailağa, Erenköy, Yahyall, Menzil, and İskerderpaşa branches. In all of these branches, the Order is known as the most politically active Sufi Order in Turkey. The rise of this Order is also correlated with the rise of the new urban middle class. Yavuz has accurately pointed out: "The Nakşibendi Orders, along with their complex web of institutions and practices, successfully expanded their influence and created new social, cultural and economic spaces that exist independent of state control." ${ }^{48}$ Given the history of Turkey's version of political secularism, this is, of course, a very significant development.

The Fethullah Gülen Movement differs from the Nakşibendi Sufi Orders. The Fethullah Gülen movement operates through networks organized in Nur reading circles scattered around the country. Moreover, with the opening of social "spaces" between the state and individuals, this neo-Nurcu-Gülen movement has gained a huge number of followers through the country, and has four main objectives. These are to (1) promote a religious-communal form of Turkish nationalism; (2) advance Anglo-Saxon secularism over the French Jacobin version; (3) seek international support for domestic endeavors; (4) challenge the Kemalist monopoly on education. ${ }^{49}$ Through time the movement has been strengthened by the foundation of a number of Nurcu media and educational institutions. After the collapse of the Soviet Union, the movement endeavored to spread into the Central Asian countries by founding Turkish schools. The Gülen Movement presently has millions of followers, great economic and political power, various media institutions, and hundreds of schools and universities all over the world. ${ }^{50}$

Along with the Sunni Islamic movements, the religious minority Alevis have also emerged as a form of civil society; given their size of approximately 10 - 15 percent of the overall population, this is particularly significant. The immigration from Anatolian town to urban areas, namely Istanbul, Ankara, and Izmir, led the Alevi population to congregate in certain areas as a group. Especially in Istanbul, violent struggles have occurred between Alevis and police forces on several occasions. Alevi identity is generally associated within Turkey's secular political discourse; starting from the late 1960s, Alevi identity increasingly took form as a political as well as a religious identity.

48. Ibid., 149.

49. Ibid., 203.

50. See Graham Fuller, The New Turkish Republic: Turkey as a Pivotal State in the Muslim World (Washington: The U.S. Institute of Peace Press, 2008). 
Two dynamics shaped that process. Parallel with rapid urbanization, newly urbanized Alevi groups sought out camaraderie. The quest for fellowship, as Ferguson defines it, is a prominent pillar of civil society. Alevi civil society grew powerfully by seeking fellowship in an otherwise alien urban setting. Also, Alevi groups grew stronger as a reaction to the revival of Sunni Islamic movements. Specifically the Gazi and Madımak events stimulated this interactive strengthening of Alevi civil society. ${ }^{51}$ The net result was a much more religiously politicized society by the time of the early twenty-first century, but with this came new problems for laiklik, since the Alevis were-and still are as of this writing - an "unrecognized" religious minority.

In response to the growing political salience of the Alev community, and as part of the shifting conception and reworking of laiklik, the AK Party government held a number of workshops to resolve the various Alevi-related issues and problems, including their religious status as minorities. However, Alevi organizations were deeply skeptical about the AK Party government's good will in this regard, and perhaps understandably, given the long history of the manner in which previous regimes discounted religious minorities. Two particular aspects of the workshops are noteworthy. First, the leading Alevi organizations, namely the Alevi Kültür Dernekleri and the Hacl Bektaş Veli Anadolu Kültür Vakfı, protested the meeting and did not attend the workshops. ${ }^{52}$ Moreover, the chairman of the Hacı Bektaş Veli Anadolu Kültür Vakfi, Ali Balkız, harshly criticized the Workshop's Report. He offered: "this report is a fraud. It is a virtual report with lack of good-will. This report does not solve problems but creates new ones. It is an AKP project that portends new steps towards Sharia-type rule." ${ }^{53}$ He added that any Alevi who accepts this report as a solution would be considered excommunicated (" $\mathrm{Bu}$ belgeyi olumlu bulanlar bizden değildir"-literally, "not one of us"). ${ }^{54}$

The Alevi community's concern regarding AK Party policies on the Alevi question and laiklik more generally stems from sensitive

51. See Oral Çalışlar, Aleviler (Istanbul: Doğan Kitap, 2009); Elise Massicard, Türkiye'den Avrupa'ya Alevi Hareketinin Siyasallaşması (Istanbul: İletişim Yayınevi, 2007); Tord Olsson, Elisabeth Ozdalga, and Catharina Raudvere, Alevi Identity: Cultural, Religious and Social Perspectives (New York: Routledge, 1998). 52. Alevi Çalıştayı Aleviler olmadan toplanacak (Alevi Workshop will meet without Alevi participation), Radikal Online, http://www.radikal.com.tr/ Radikal.aspx?aType=RadikalDetay\&ArticleID=977190\&CategoryID=77 (accessed January 28, 2010).

53. In the original Turkish, the statement was: Rapor bir aldatmacadır. Sanaldır, maksatlıdır, iyi niyetten yoksun, sorun çözen değil yeni sorunlar yaratan, şeriata doğru giden yolda yeni adımlar öngören bir AKP projesidir.

54. Hükümete zehir zemberek çıkıs:: Sünni ulema gibi!, CNN Turk, http://www. cnnturk.com/2010/turkiye/02/12/alevi.calistayi.raporu.alevileri.boldu/563501. 0/index.html (accessed February 12, 2010). 
historical dynamics - in this sense, significantly, the regime's treatment of the Alevi community is emblematic of its orientation toward laiklik. The Ministry of Religious Affairs is dominated by the Sunni branch of Islam; therefore, the Alevi community favors abolishing this institution. Second, the Alevi worship places, called Cemevi, are not considered temples or mosques as such and are thus not officially recognized by the state; Alevi groups object to this. Third, Alevis advocate the abolition of obligatory religion courses in elementary and high school. Since these courses generally focus on Sunni Islam, the Alevi community regards their content as alien. Finally, Alevis object to a law dating to 1924 which banned the dervish lodges. According to that law, no one shall be titled "Baba," "Şeyh," "Derviş," etc. Since the religious title of "Baba" is used by Alevi leaders and preachers, these leaders have no formal recognition or status recognized by the state, and are technically outside the law. ${ }^{55}$ This is no small matter, since religious leaders are appointed by the national Ministry of Religious Affairs. Resolution of the Alevi question thus requires a shift of Turkey's entire secular conception, almost certainly toward one more along the lines of a "passive secular" state. For now, however, the Alevi community remains skeptical of AK Party government gestures, since the above-mentioned core political requests of the Alevi community remain unresolved, and the Workshop Report resolutely rejected by the Alevi groups. The first step, perhaps, might even be an essentially symbolic but politically meaningful gesture, such as the founding of a memorial museum to Madımak Oteli, who holds a significant and defining role in Alevi communal memory and identity. But this request has also been rejected by the regime.

There is also a new dimension of liberalized civil society which supports change in the meaning of laiklik. The liberal-leftist community includes pro-EU intellectuals and leftist-liberals who view traditional laiklik as too constrictive. However, the impact and practical participation of such groups remain quite small, especially compared with the power of the business elite or religious networks. Nonetheless, Ahmet İnsel, a former member of New Left Party Initiative, defines their understanding of secularism as:

Laiklik means separation of religious affairs from government. But the Ottoman and modern Turkish state traditions in fact never experienced such a separation. In (genuine) laiklik, the state would not intervene into religious affairs; if it does, then the state itself becomes a part of the religion. Therefore, our understanding of secularism would be for the state to fully extract itself from religious affairs. There would thus be neither

55. Taha Akyol, “Alevi Açılımı ve Laiklik,” Milliyet, February 16, 2010. 
obligatory religious courses nor even a Ministry of Religious Affairs itself, as a state institution. ${ }^{56}$

Such a characterization will, of course, sound very familiar to Americans, since it clearly reflects a "passive secular" orientation on the part of the state. We find it highly significant that calls for such an orientation in Turkey are coming from so many disparate sources, largely based on an energized, increasingly vibrant civil society.

Yet the transition to such a civil society has deepened the divides in Turkey, and particularly in the political realm. The rising power of various religious movements sparked serious reaction from Turkey's traditionally secular elite. Moreover, the AK Party government's Islamic background and orientation necessarily and inevitably raised skepticism among nonreligious groups, even among those who also favored change in the effective political substance of laiklik, even if for somewhat different reasons-namely political prudence. If the AK Party government should fail to demonstrate good will and create political conditions in which a general consensus among these groups might be found, then Turkey's reformation and transition regarding laiklik could be postponed or thwarted altogether. Moreover, Turkish society would almost certainly slide into an even harsher, deeper political distrust and polarization than has emerged thus far. At this point it is useful to consider the broader international framework in which this deepening polarization within Turkish society is occurring.

\section{Religion and State in Contemporary Turkey: The External Dimension}

A dynamic process of interaction between domestic and international politics has affected religion-state relations in Turkey,

56. In the original Turkish:

Laiklik devletle din işlerinin ayrılmasıdır. Bu Osmanlı-Türkiye Sünni devlet geleneğinin hiç bilmediği bir şey. Laiklikte devlet din alanına girmez, girdiği andan itibaren devlet taraftır. Dolayısıyla bizim laiklik anlayışımız, devletin din alanından bütünüyle çekilmesidir. Ne zorunlu din eğitimi, ne devlet politikası olarak Diyanet İşleri Başkanlığı kesinlikle söz konusu olamaz.

Ahmet İnsel'Yeni Sol'u anlatıyor, Radikal Online, http://www.radikal. com.tr $/$ Radikal.aspx?aType=RadikalDetay\&ArticleID=980992\&Date=19. 02.2010\&CategoryID=78 (accessed February19, 2010). Also for more on Turkish Left, see: Murat Belge, "Nationalism, Democracy and the Left in Turkey," Journal of Intercultural Studies 30, no. 1 (2009): 7-20. Ahmet İnsel, Solu Yeniden Tanımlamak (Istanbul: Birikim Yayınları, 2009). 
particularly since the early-to-mid-1990s. This is due to several major dimensions of Turkish foreign policy. These are numerous, but the most significant are: (1) relentless pursuit of EU accession by every civilian Turkish government since the 1960s; (2) geopolitical fallout of the collapse of communism in the former USSR and Eastern Europe, particularly Turkey's relations with Russia; (3) the so-called war on terrorism led by the United States and selected allies since 2001; and (4) the larger pattern of regional dynamics, particularly the confounding intermix of issues related to Turkish-Armenian relations and the closely related matter of Nagorno-Karabagh. The picture is complicated by the fact that each of these major dimensions of foreign relations has affected religion-state relations in Turkey rather differently. In aggregate, however, it appears that the interplay of domestic social and political change with the more pressing contemporary foreign policy issues has had the effect of further pushing Turkish laiklik in the direction of "passive secularism."

(1) The EU accession process must be placed at the top of the list of factors that have most directly affected religion-state relations in Turkey. The prospect of EU membership catalyzed significant political change in Turkey. ${ }^{57}$ This process has been critically important to the formation, and re-formation, of political ideas and sense of political identity. ${ }^{58}$ An important question, it seems, is whether the social forces noted in previous sections of this article would have effectively given rise to a more passively secular state, in and of themselves. But that question is essentially a counterfactual one and beyond the scope of this essay. At the very least, nonetheless, the prospect of EU membership worked in conjunction with an increasingly fertile domestic political environment for such a shift in the character of laiklik to occur. According to a recent consideration of this matter, the prospect of EU membership may have been the critical element in this shift:

[T]he transformation of Turkish political Islam has produced an alternative, liberal version of secularism; yet, it has not resolved deep social divisions. Building a liberal consensus between religious conservatives and secularists is imperative for the resolution of deep social divisions in

57. Paul Kubicek, “The European Union and Democratization 'From Below' in Turkey" (presented paper at the biannual conference of the European Union Studies Association, Austin, Texas, March 31-April 2, 2005), 15; available online at aei.pitt.edu/3018/02/kubicek-austin_paper.doc (accessed February 25, 2010).

58. Paul Kubicek, “The European Union, European Identity, and Political Cleavages in Turkey" (presented paper at the biannual conference of the European Union Studies Association, Los Angeles, California, April 23-25, 2009); available online at http://www.unc.edu/euce/eusa2009/papers/kubicek_04D.pdf (accessed November 19, 2009). 
Turkey. The European Union as a guarantor and initiator of reform could play a major role in building trust between the secularist and the religious conservative segments of society. ${ }^{59}$

(2) The collapse of communism in Eastern Europe in 1989 and in the USSR in 1991 eliminated the military and ideological threat posed by the USSR and its allies; Turkey nonetheless continued membership in NATO. We noted above the general shift in threatperception within Turkey during the 1990s from primarily external threats to internal ones. At least two large-scale political changes occurred as a result: first, relations with Russia began to dramatically improve, particularly in the first Erdogan administration ${ }^{60}$; and second, by focusing on the perceived internal threats of radical Islam and Kurdish separatism, the door was opened politically for a fundamental reconceptualization of the meaning of laiklik precisely because the magnification of the salience of these issues demanded a rethinking of what it means to be a "secular state."

Turkish relations with Russia were historically not good until the time of the Turkish Republic, and during the Cold War were generally characterized by distrust and suspicion even amid considerable cooperation on some issues such as trade and technological assistance. ${ }^{61}$ Nonetheless, significant commercial ties began to develop even during the Cold War, particularly during the first Erdogan administration (2002-2007), and dramatically improved relations emerged. ${ }^{62}$ It is difficult if not impossible to gauge the degree to which the Russian-Turkish rapprochement of the 2000s was

59. Ioannis N. Grigoriadis, "Islam and Democratization in Turkey: Secularism and Trust in a Divided Society," Democratization 16, no. 6 (2009): 1194.

60. Igor Torbakov, "Making Sense of the Current Phase of Turkish-Russian Relations," Jamestown Foundation Occasional Paper (October 2007), http:// www.jamestown.org/uploads/media/Jamestown-TorbakovTurkeyRussia.pdf (accessed February 22, 2010).

61. Erel Tellal, Uluslararasi ve Bölgesel Gelismeler Cercevisinde: SSCB-Turkiye Iliskileri 1953-1964 (Ankara: Mulkiyeliler Birligi Vakfı Yayınları, 2000).

62. See Lerna Yanik, “Allies or Partners? An Appraisal of Turkey's Ties to Russia: 1991 - 2007," East European Quarterly XLI, no. 3 (2007): 349 - 70; James W. Warhola and William A. Mitchell, "The Warming of Turkish-Russian Relations: Motives and Implications," Demokratizatsiya: The Journal of Post-Soviet Democratization (Winter 2006): 127-43; and Igor Torbakov, ibid., who as of 2007 remained quite skeptical about the prospects for further and durable Turkish-Russian rapprochement. For an updated view, and one that is considerably more optimistic about the prospects for the solidification and advancement of closer TurkishRussian relations, see Ilyas Kamalov, "Rusya'da Turk Yili ve Turk-Rus Iliskilleri," Stratejik Analiz, no. 98 (June 2008), 6, and particularly Bulent Aras, "Turkey and the Russian Federation: An Emerging Multi-Dimensional Partnership," SETA Policy Brief 35 (August 2009), available online at http://www.setav.org/index. php?option=com_content\&task=view\&id=935\&Itemid=68 (accessed 22 February, 2010). 
motivated on Russia's part by strategic considerations regarding religion; however, it is clear from Russia's own experience with radical, Islamic-based terrorism that the last thing Russia would want is a "radically Islamicized" Turkey so near its own southwestern flank. Perhaps the eagerness with which Russia has pursued closer relations with Turkey has been augmented by a desire to help entrench a politically moderate regime (regarding religion, at least) in Turkey. Viewed from Moscow's perspective, a moderately religious AK Party-led Turkey is surely preferable to an Iran-type clerical regime-and also to a staunchly pro-Western, "actively secular" military establishment such as that which brought about the "soft coup" of February 1997. Interestingly, the increased interweaving of religious symbolism and motifs in Russian high politics in the 1990s occurred more or less simultaneously with the escalation of partisan strength of religious-oriented parties in Turkey; this is not to suggest that the two trends were causally related, but it is clear that the dramatic turn in Turkish-Russian relations in 20042005 occurred with the Kremlin quite comfortable in cooperating with an avowedly Islamic-oriented government. The Turkish secular elite's angst with the AK Party government was simply not shared by Moscow. As of this writing, Turkish-Russian relations have only continued to improve.

(3) The U.S.-led "war on terrorism" beginning in 2001 profoundly affected Turkish domestic and foreign policy, with short, medium, and long-term consequences. One particularly notable effect was the energizing of anti-American sentiments in a manner that has ironically created more hospitable domestic political conditions for the emergence of an American-type disposition to the question of religion-state relations. The "war on terrorism" spawned antiAmerican sentiments in Turkey that almost certainly would not have otherwise emerged. These have to do with: (1) the war in Iraq and its complex reconfiguring of the Kurdish issue in Turkey and the region; (2) the diplomatic attitude of the United States, and (3) specific policies pursued toward Turkey. As noted by Aylin Guney in 2008, "all segments of Turkish society as well as the state have become intensely critical of American policies to an extent that has not been seen before." ${ }^{63}$ Again, ironically, the disposition of the Turkish government toward the meaning and outworking of laiklik took on an increasingly American-type orientation and all the while anti-American sentiments steadily rose. A more detailed

63. Aylin Guney, “Anti-Americanism in Turkey: Past and Present," Middle Eastern Studies 44, no. 3 (2008): 484. See also her article "An Anatomy of the Transformation of the US-Turkish Alliance: From 'Cold War' to 'War on Iraq'," Turkish Studies 6, no. 3 (2005): $341-59$. 
and expansive explanation of how and why this occurred remains outside the scope of this brief essay, but certainly warrants investigation.

(4) Finally, the tangled political, military, and cultural relations with the Caucasus region, especially Azerbaijan and Armenia, must be taken into account in reckoning the foreign policy considerations influencing the meaning of laiklik at home. Such influences appear to be more indirect than direct. Nonetheless, Turkey's more or less consistent and unequivocal support for Azerbaijan, against Armenia on Nagorno-Karabagh, and on most other matters, included a religious dimension. The interplay of domestic and international factors on these matters is exceptionally complex, and can only be briefly touched on here. It is by no means clear that the momentum gained in 2008-2009 from the so-called football diplomacy will continue and manifest itself in friendly, trusting relations. Paradoxically, however, the diplomatic opening with Armenia in 2008 that signaled a sea change in bilateral relations was more likely to have occurred on the basis of the AK Party's broad foreign policy of "no enemies" and also upon a moderately religiously oriented governmental disposition than the previously hardline, essentially nationalist disposition pursued by previous regimes which viewed laiklik as rigidly as they viewed the prospect of reconciling with as previously implacable a diplomatic foe as Armenia. There is no hard evidence that the relation was causal, but it is noteworthy that, from an American "passive secular" perspective at least, the conciliatory moderation in this domain of foreign policy came from an administration that pursued a similar moderation with regard to the crucial question of religion-state relations.

\section{Conclusions: Future Directions of Religion-State Relations?}

The Republic of Turkey was established as a secular state in the early 1920s, and has remained so ever since. The meaning of that phrase is ambiguous in any context, however, and each political regime founded upon the principle of a secular state necessarily possesses unique features. Turkey's secular state was clearly of the "active secular" type for nearly the entire history of the Republic, as evidenced by strict control of religious leadership, education, formal recognition (or lack thereof) of religious communities, and in general a state-controlled political climate in terms of the role of religion in the public sphere. That has all been subtly but unmistakably changing during the 2000s, and appears quite likely to 
continue doing so for the foreseeable future. It will likely do so in a manner that manifests itself in changes in the political structure itself, even though it is not likely-at all-that the bedrock principle of laiklik will even be seriously questioned, let alone abandoned. That is not the issue; instead, the issue is what does laiklik mean? The short answer is that laiklik has been slowly, subtly, but significantly shifting in the direction of a "passive secular" type of statereligion relation. This shift is occurring amid transformation in the character of Turkish society itself. The political significance of this aggregate of changes is profound and widespread. Should it continue, it would appear to more or less definitively answer the question dogging Western theoretical social science (and policy discourse as well) about the prospect of liberal democracy (as religious freedom, understood from an American, passive secular perspective at least) successfully functioning in a predominantly Moslem society. In some respects, that question would appear to have been answered by the fact that most Moslems in the world were living in countries designated "free" or at least "partly free" according to the 2009 reckoning of Freedom House-e.g., Indonesia, Bangladesh, Senegal, and others well beyond Turkey. ${ }^{64}$

The change in laiklik in Turkey may also have significant, widespread ramifications for foreign relations among countries in the region, and perhaps far beyond. If nothing else, the shift toward a more moderated degree of state control of religion, specifically toward a more "passively secular type," could well have the effect of blunting the attraction of radicalized religion. It is also possible that such moderation will help provide a political foundation for coping with the deepening polarization within Turkish society, noted variously in this essay and elsewhere. ${ }^{65}$ Thus in this case, as in so many other domains of governance, the classic, timehonored, and cardinal virtue of moderation will be seen to have numerous and compounding benefits.

64. "Freedom in the World," Freedom House, http://www.freedomhouse.org/ template.cfm?page=15 (accessed March 1, 2010).

65. "Turkey in Transit: Democratization in Turkey," Special Report, Freedom House; available online at http://www.freedomhouse.org/uploads/special_ report/65.pdf (accessed February 26, 2010). The report concludes:

Overall, Turkey has shown impressive progress in democratic political reform, economic liberalization and serious commitment to Europeanoriented reforms.... Over the coming years, however, even more effort is needed to overcome the often bruising political polarization, while making sure that gains in freedom of expression, human rights, and good governance are taking roots and the risk of backsliding is avoided. 